UDK 536.24.2: 532.5.529.5

Doroshenko A. V. ${ }^{1}$, Glauberman M. A. ${ }^{1}$, Shestopalov K.O. ${ }^{1,2}$, Bodnia A. S. ${ }^{3}$, Khalak $V . F^{l}$

${ }^{1}$ Institute of refrigeration, cryotechnology and eco-energy, Odessa National Academy of Food Technologies, 112 Kanatnaya str., Odessa, 65039, Ukraine,

${ }^{2}$ Ningbo Institute of Technology, Zhejiang University, № 1 QuianHu South Road,

${ }^{3}$ Ningbo City, 315100, Zhejiang Province, China,

E-mail:dor_av43@i.ua,gmchen@zju.edu.cn

\title{
Evaporative coolers of gases and liquids with a lowered level of cooling
}

This study is dedicated to the creation of the schematic solutions of the evaporative cooling and air conditioning systems, development of the heat and mass transfer equipment for such systems, experimental investigation and analysis of principle possibilities of such systems on the basis of carried out theoretical and experimental research. The theoretical modeling of the coupled heat and mass transfer process in indirect evaporative coolers of water and air is carried out. It is shown that the dew point temperature of the air flow entering the evaporative cooler can be served as a limitation of cooling. The difficulties connected with obtaining the cooling limitation for low-temperature cooling connected with the possible condensation of water vapor in the air flows, when the air flow contacting with water becomes fully saturated before going out from the heat and mass transfer device, are studied.

Keywords: Evaporative Coolers, Natural Cooling, Air-Conditioning, Energy Saving

\begin{tabular}{|c|c|c|c|}
\hline \multicolumn{4}{|c|}{ omenclature } \\
\hline & flow rate $\left(\mathrm{kg} \mathrm{m}^{-3}\right)$ & $p$ & pressure $(\mathrm{Pa})$ \\
\hline & thickness of the liquid layer (m) & $q$ & specific heat flow $\left(\mathrm{W} \mathrm{m}^{-2}\right)$ \\
\hline & heat transfer coefficien & & temnerature $\left({ }^{\circ} \mathrm{C}\right)$ \\
\hline & flow rate ratio & $\varphi$ & relative humidity $(\%)$ \\
\hline
\end{tabular}

Introduction. The interest to the possibilities of the evaporative cooling has been increased recently. It is caused by their small energy consumption and by their environmental loyalty (Chen et al., 2015; Doroshenko and Glauberman, 2012). Both direct evaporative coolers (DEC - air coolers and water coolers, cooling towers $(\mathrm{CTW})$ ) and indirect evaporative coolers (IEC) find a wide practical application. The capabilities of such coolers according to the achievable level of cooling are limited by wet bulb temperature of the outside air $t_{\mathrm{wb}}$. This temperature is a natural limitation of cooling. The efficiency of such systems depends essentially on local climatic conditions. The evaporative coolers with decreased level of cooling have been intensively studied recently (Maisotsenko and Gillan, 2003; Pandelidis et al., 2015; USA Patent 2009/0007583; USA Patent 2004/0061245; USA Patent 6,494,107). The purposes of the present study are the extension of the practical area of application of evaporative water and air coolers; design of the corresponding new solutions, and particulariza- 


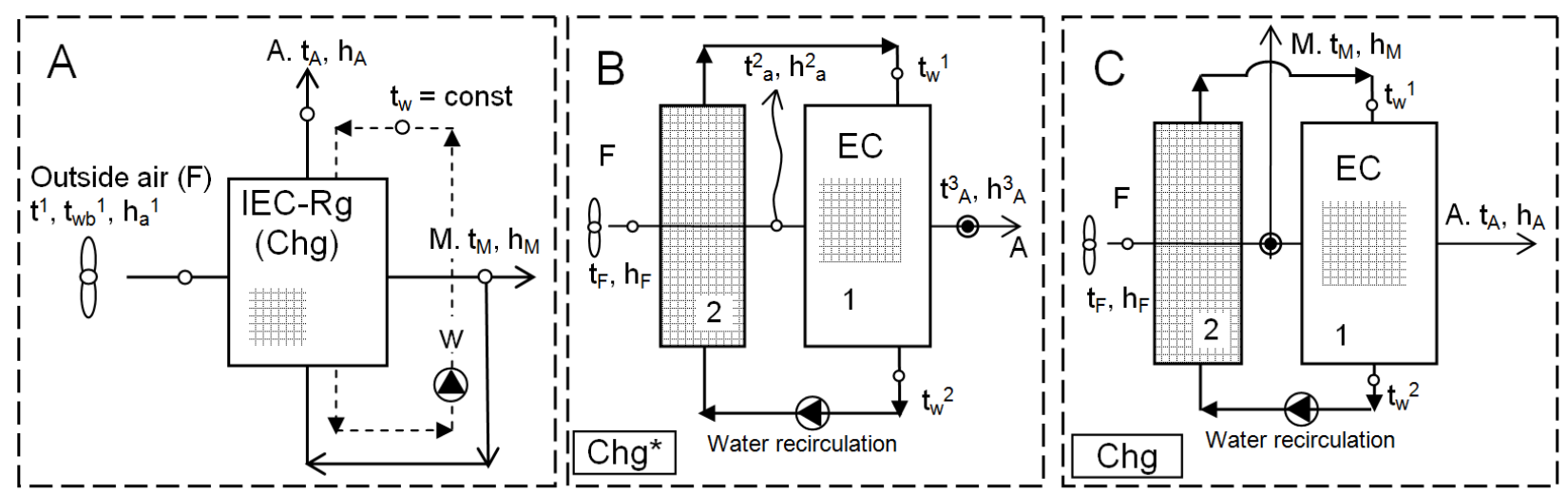

Fig. 1. Transition from combined scheme of IEC-Rg (A)

to separated schemes of air cooler Chg (B and C):

1 - evaporative air cooler; 2 - water-air heat exchanger

tion of the conditions for realization of the low-temperature cooling, primarily, the determination of optimal ratios of contacting flows.

In IEC of air (Fig. 1), which have become the most widely used recently, the air flow (F) entering for cooling, is divided into two parts. The auxiliary air flow (A) enters the "wet" part of the cooler, where it contacts with water film, flowing down on the surface of the channel (water recirculates through the packing of the device). The evaporative cooling of water is realized here. The chilled water provides a contactless cooling of the main air flow (M) through the wall, which separates the channels. The main air flow is cooled at constant humidity content: this provides the advantages during construction of the air conditioning systems based on the IECa. Auxiliary air flow rejects the heat from the device, its temperature also decreases, and humidity content is increased. Temperature of water in the cycle is constant and it is a little higher than the wet bulb temperature of the outside air entering the IECa. This temperature depends on the ratio of the air flows in IECa, and it is considered as a limitation of cooling for both air flows.

Indirect evaporative coolers of gases can be of ordinary or regenerative types (Chen et al., 2015; Pandelidis et al., 2015; USA Patent 2009/0007583). In a regenerative cooler (Fig. 1A) the separation of the air flows takes place at the exit of the "dry" zone of the device (in the inner heat exchanger). This system is marked as IEC-Rg (air chiller Chg). Here the auxiliary air flow enters the evaporative part of the cooler; it is already chilled at constant humidity content. Its cooling potential is substantially increased and the limitation of cooling is decreased theoretically to the dew point temperature of the ambient air $t_{\mathrm{dp}}{ }^{1}$. The concern to the capabilities of the solutions of Chg diagram in literature is large (Chen et al., 2015; Pandelidis et al., 2015; USA Patent 2009/0007583), but the results of the studies do not take into account the concomitant circumstances, which are to be discussed in the present study. In a polytropic process of the evaporative cooling of water in a water chiller (CTW) the limitation of evaporative cooling is determined by the wet bulb temperature of air entering the device. Fig. 1B represents the system where cooled and humid air is delivered to the room (Chg*); Fig. 1C represents the system where cooled air is delivered to the room (Chg), but its humidity content is not changed. 


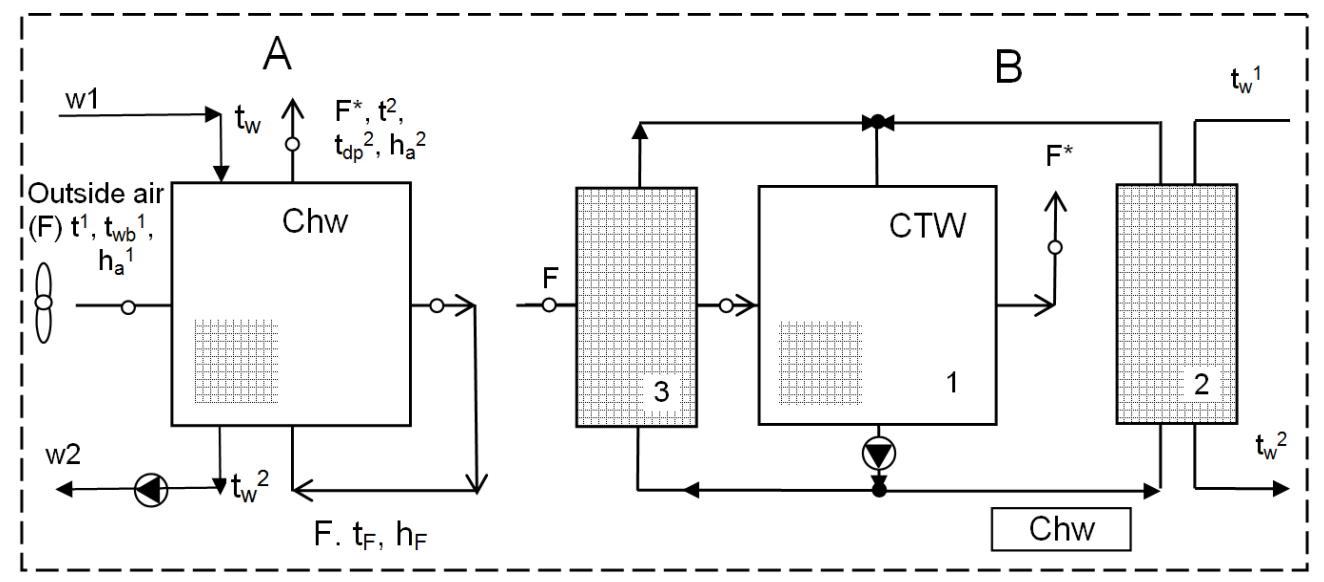

Fig. 2. Schematic diagrams of indirect evaporative coolers of water: combined $(\mathrm{A})$ and separated (B) schemes: 1 - cooling tower, 2 - loading heat exchanger (the object which is cooled by a chiller), 3 - water-air heat exchanger

Fig. 2 presents the schematic diagrams of the indirect type water chillers $(\mathrm{Chw})$ which are realized in combined (Fig. 2A) and separated modes (Fig. 2B). The water cooler IECW is similar to the air cooler IECg, but the main difference is that the main product flow in IECW is the chilled water. This design can be considered as a twocomponent cooling tower, in which the product water is chilled contactless. The process in "wet" channels is fully similar to IECg. In a chiller-water cooler Chw the limitation of cooling theoretically is also decreased to the dew point temperature of ambient air $t_{d p}{ }^{1}$.

Based on the previously carried out studies (Chen et al., 2015; Chen et al., 2018; Doroshenko and Glauberman, 2012), it was determined, that the regularized symmetrical packing with vertical or inclined channels is the optimal choice for the design of the film evaporative heat and mass transfer devices (channels can be closed-loop or partially closed loop). The main problems for such design are: the packing layer should be unified, i.e. can be used for both counter flow and cross-current flow of air and water contact - this is particularly important for the indirect evaporative coolers; the packing should have a large specific surface with small resistance to air flow; the density of the layer is selected considering a stability of the system, as well as possible sedimentation on the working surfaces; the packing should have corrosion resistance to working fluids, it should be of a simple construction and manufacturable; the packing layer should assist the uniform input of liquid and its favorable distribution between neighboring channels (the problem of wettability of the multichannel packing surface) - the appropriate material for packing manufacturing should be selected. In recent decade, mainly the polymeric materials have been used for manufacturing the film type heat and mass transfer equipment: high density polyethylene, highimpact polystyrene, polyvinylchloride, polypropylene (Gómez et al., 2005; Martínez et al., 2011; Koltun et al., 2003).

Weak wettability of the polymeric materials can be compensated by manufacturing of the complex form of the surface by creation of microtoughness on the surface of the packing elements, and by application of various distributors of gases and liquids. One of the prospective materials for application for these purposes is a polycarbonate (PC). The honeycomb panels made from PC are characterized by high me- 


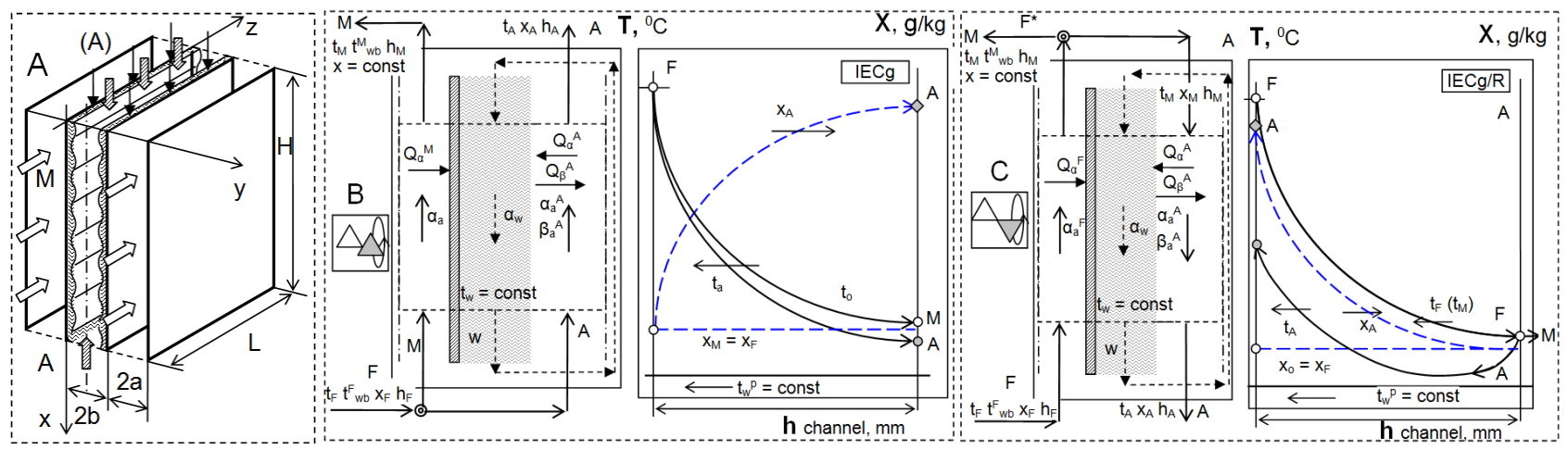

Fig. 3. Modeling of the coupled heat and mass transfer in IEC of air:

A - design scheme; B - IECg; C - IECg/R

chanical characteristics, such as solidity, persistence to impact influence at continuous exposition on open air.

II. Modeling of the process of the coupled heat and mass transfer in evaporative air cooler of indirect type. The element of the packing with dimensions of $0 \leq x \leq H,-a \leq y \leq b, 0 \leq z \leq L$ (Fig. 3A) is considered for description of the heat and mass transfer in IECg for the condition of material homogeneity of flows. The main flow of air is cooled through the separating wall on account of evaporative cooling of water flowing down if a form of film. The auxiliary air flow contacts directly with liquid (schemes of gases and liquids contacts in "wet" channels are considered as parallel flow as well as counter flow).

The equation of coupled heat and mass transfer in IECg and corresponding matching conditions in a form of equations of boundary layer:

- for liquids $(0 \leq x \leq H, 0 \leq y \leq h$ ( $h$ - the thickness of the liquid layer), $0 \leq z \leq l)$, temperature $t_{\mathrm{w}}=t_{\mathrm{w}}(x, y, z)$ is determined from equation:

$$
W_{w}(y) \frac{\partial t_{w}}{\partial x}=a_{w} \frac{\partial^{2} t_{w}}{\partial y^{2}},
$$

condition at entrance at $x=0$, is: $t_{w}(0, y, z)=t_{w}^{0}$;

- for auxiliary air flow «A» $(0 \leq x \leq H, h \leq y \leq b, 0 \leq z \leq l)$, temperature $t_{\mathrm{A}}=t_{\mathrm{A}}(x, y$,

$z$ ) and partial pressure of vapor $p_{\mathrm{v}}=p_{\mathrm{v}}(x, y, z)$ is determined by the equations:

$$
\begin{aligned}
& W_{A}(y) \frac{\partial t_{A}}{\partial x}=\frac{\partial}{\partial y}\left[\left(a_{a}+a_{a}^{T}\right) \frac{\partial t_{A}}{\partial y}\right], \\
& W_{A}(y) \frac{\partial p_{n}}{\partial x}=R_{n} T_{A} \frac{\partial}{\partial y}\left[\left(D_{a}+D_{a}^{T}\right) \frac{\partial p_{n}}{\partial y}\right],
\end{aligned}
$$

at $x=0: t_{A}=t_{B}^{0}, p_{V}=p_{n}^{0}$; at $y=b: \frac{\partial t_{A}}{\partial y}=0, \frac{\partial p_{n}}{\partial y}=0$.

- for main air flow "M" $(0 \leq x \leq H,-a \leq y \leq 0,0 \leq z \leq L)$ temperature $t_{\mathrm{M}}=t_{\mathrm{M}}(x, y, z)$ is determined from equation: 


$$
\begin{aligned}
& W_{M}(y) \frac{\partial t_{M}}{\partial x}=\frac{\partial}{\partial y}\left[\left(a_{a}+a_{a}^{T}\right) \frac{\partial t_{M}}{\partial y}\right], \\
& \text { at } z=0: t_{M}=t_{M}^{0} ; \text { at } y=-a: \frac{\partial t_{M}}{\partial y}=0
\end{aligned}
$$

- the matching conditions: on the wall at $y=0, q_{0}=k_{\alpha}\left(t_{A}-t_{w}\right)$, where $q_{0}$ - heat flow, $k$ - heat transfer coefficient through the wall with thickness of $\delta_{w}$ and thermal conductivity $\lambda_{w}$ :

$$
k=\frac{1}{\frac{1}{\alpha_{M}}+\frac{\delta_{w}}{\lambda_{w}}+\frac{1}{\alpha_{A}}} ;
$$

At $y=h p_{\mathrm{M}}=p ”, q=q_{\alpha}+q_{\beta}$ (on the interface). The following set of equations can be obtained by averaging the above equations:

$$
\left\{\begin{array}{l}
\frac{\partial t_{w}}{\partial x}=a_{1}\left(t_{A}-t_{w}\right)+b_{1}\left(p-p^{\prime \prime}\right)+c_{1}\left(t_{M}-t_{w}\right) \\
\frac{\partial t_{A}}{\partial x}=a_{2}\left(t_{w}-t_{A}\right), \frac{\partial p}{\partial x}=b_{2}\left(p^{\prime \prime}-p\right) \\
\frac{\partial t_{M}}{\partial z}=c_{2}\left(t_{w}-t_{M}\right)
\end{array}\right.
$$

The boundary conditions: at $x=0 \quad t_{w}=t_{w}^{0}, t_{A}=t_{A}^{0}, p=p_{0}$; at $z=0 t_{M}=t_{M}^{0}$. Coefficients $a_{1}, b_{1}, c_{1}, a_{2}, b_{2}, c_{2}$ can be determined from the relations:

$$
a_{1}=\frac{\alpha}{c_{w} g_{w}}, \quad b_{1}=\frac{r_{D} \beta_{p}}{c_{w} g_{w}}, \quad c_{1}=\frac{k}{c_{w} g_{w}}, \quad a_{2}=\frac{\alpha}{c_{a} g_{A}}, \quad b_{2}=1.61 \frac{p_{b} \beta_{p}}{g_{A}}, \quad c_{2}=\frac{k}{c_{a} g_{M}} \text {. }
$$

Linear theory of the evaporative coolers is considered; coefficients $a_{1}, b_{1}, c_{1}, a_{2}$, $b_{2}, c_{2}$ are constants; for the partial pressure of the saturated vapor $p$ " the nonlinear relation was used:

$$
p^{\prime \prime}(t)=690.5 \exp (00608 t) \text {. }
$$

Equation (6) can be presented as following:

$$
\left\{\begin{array}{l}
\frac{\partial t_{w}}{\partial x}+c_{0} t_{w}=a_{1} \theta_{A}+b_{1}\left(p-p^{\prime \prime}\right)+c_{1} t_{M}, \quad c_{0}=a_{1}+c_{1} \\
\frac{\partial t_{A}}{\partial x}+a_{2} t_{A}=a_{2} t_{w}, \quad \frac{\partial p}{\partial x}+b_{2} p=b_{2} p^{\prime \prime}, \quad \frac{\partial t_{M}}{\partial z}+c_{2} t_{M}=c_{2} t_{w}
\end{array}\right.
$$

Here we consider the numerical solution of the problem; the explicit difference scheme (method of Euler) was used as an algorithm:

$$
\begin{aligned}
& t_{w j}^{i+1}=\left(1-c_{0} \Delta x\right) t_{w j}^{i}+\left[a_{1} t_{A j}^{i}+b_{1}\left(p_{j}^{i}-p_{j}^{\prime i}\right)+c_{1} t_{M j}^{i}\right] \Delta x \\
& t_{A j}^{i+1}=\left(1-a_{2} \Delta x\right) t_{A j}^{i}+a_{2} t_{w j}^{i} \Delta x, \\
& p_{j}^{i+1}=\left(1-b_{2} \Delta x\right) p_{j}^{i}+b_{2} \Delta x p_{j}^{\prime i} \\
& t_{M j+1}^{i}=\left(1-c_{2} \Delta z\right) t_{M j}^{i}+c_{2} \Delta z t_{w j}^{i}
\end{aligned}
$$


where $i, j$ determine the corresponding anchor point on axes $x$ and $z$, and $\Delta x$ and $\Delta z-$ are the steps of difference grid. According to the boundary conditions for the boundary anchor points the following relations can be obtained:

$$
t_{w j}^{0}=t_{w}^{0}, t_{A j}^{0}=t_{A}^{0}, p_{j}^{0}=p_{0}, j=1,2, n, t_{M 0}^{i}=t_{M}^{0}, i=1,2,, m
$$

The representative profile changes of the main parameters of main " $\mathrm{M}$ " (temperature of the chilled flow at constant humidity content) and auxiliary "A" (temperature and humidity content) air flows in IECg and IEC-Rg by length and by height of the considered module are presented in Fig. 3.

III. Experimental study of the processes of evaporative cooling in lowtemperature evaporative coolers. The test rig provides the possibility of study the working processes: in direct evaporative water chiller (CTW) and low temperature cooler-chiller Chw, as well as air cooler IECg. The air is taken from the environment by fan, then it undergoes thermal and humidity handling, and is transferred to the working chamber, where the evaporative cooler is located. Dimensions of the chamber were: $460 \times 400 \times 180 \mathrm{~mm}$, full air flow capacity was $3500 \mathrm{~m}^{3}$ hour ${ }^{-1}$. The flowmeter was placed on the air line; flow rate regulators were located on the bypass line. The pump with adjustable capacity provides the circulation of water. The water flow rate was determined by set of flowmeters. The packing of the heat and mass transfer device was made as a film type counter flow apparatus; the main element of the packing was two-layer multichannel PC plate with channels of complex configuration. A thin film of liquid is flowing down through the channels of the packing elements interacting with air flow. The shape of the channels is formed by multiple decussation of thin-walled polymeric plates placed under various angles; this provides accumulation of liquid and its retention in packing (fluid retention). A high reliability and stiffness of the whole construction of the packing is realized as well. Such configuration of the channel improves uniform distribution of liquid along the whole surface of the packing, and it provides approximation of the wetted surface to the construction surface of the device packing. Water collector consists of five pockets. This provides the differential measurement of the liquid flow rate along the whole cross section of packing module. The test rig provides the possibility to study the designed evaporative coolers with packing made from polymeric materials with multichannel regular structure. Preliminary calculations (Doroshenko and Glauberman, 2012; Foster and Dijkastra, 1996; McNab and McGregor, 2003; Stoitchkov and Dimirov, 1998; Zhao et al., 2008; Gómez et al., 2005) showed that the polymeric materials can be used in the construction of evaporative coolers without substantial decrease in efficiency of the device, because the thermal resistance of the walls of the channel is comparable to the thermal resistance of the liquid film located on the outer surfaces. This is confirmed by the data of the Australian study (McNab and McGregor, 2003). During the experiments, the value of the equivalent diameter of working channels was $22 \mathrm{~mm}$; the working velocities of the air motion in the channels of the packing were changed in the range of $w_{\mathrm{a}}=1.0-4.0 \mathrm{~m} \cdot \mathrm{s}^{-1}$; water concentration (water spray rate) of packing was $5-18 \mathrm{~m}^{3} \cdot\left(\mathrm{m}^{2} \cdot \mathrm{h}\right)^{-1}$; humidity content was changed in the range from 8 to $18 \mathrm{~g} \cdot \mathrm{kg}^{-}$ ${ }^{1}$. Measurement error of the main values, caused by the accuracy of measurements, 
was calculated during data processing for each experiment; for the heat balance the error was $12 \%$; experimental material was characterized by the reliable reproducibility. The program of the research covered to study hydro-aerodynamics and heat and mass transfer for various regimen of the evaporative cooling of air and water. A water-air heat exchanger was included to the test rig to study the chiller-water coolers Chw; part of the chilled water from the evaporative water cooler was delivered to a water-air heat exchanger for preliminary cooling of air flow.

IV. Analysis of obtained results. In this section the analysis of operation of evaporative air cooler IECg is performed for various ratios of main and auxiliary air flows of $l^{*}=G_{\mathrm{M}} / G_{\mathrm{A}}: 1-1.5 ; 2-1.0 ; 3-0.5$; the influence of the temperature and humidity content of air at the entrance of IECg was studied as well. For IECg, the wet bulb temperature $t_{\mathrm{wb}}{ }^{1}$ of total air flow can be considered as the natural limitation for evaporative cooling of main and auxiliary air flow, increased by a certain value depending on the ratio of the air flows $l^{*}=G_{\mathrm{M}} / G_{\mathrm{A}} ; t^{0}=t_{\mathrm{wb}}{ }^{1}+\Delta t^{*}$. This is connected with the process of heat transfer from the main flow to the auxiliary flow through the dividing wall and flowing down liquid film on surface of the "wet" channel, as well as with corresponding increase in temperature of the liquid recirculating through the "wet" part of the device $\left(t_{\mathrm{w}}{ }^{\text {rec }}\right)$; this temperature remains constant.

Thermal efficiency of IECg according to main and auxiliary air flows can be determined from:

$$
\begin{aligned}
& E_{\mathrm{M}}=\left(t_{\mathrm{M}}{ }^{1}-t_{\mathrm{M}}{ }^{2}\right) /\left(t_{\mathrm{M}}{ }^{1}-t^{0}\right) ; E_{\mathrm{A}}=\left(t_{\mathrm{A}}{ }^{1}-t_{\mathrm{A}}{ }^{2}\right) /\left(t_{\mathrm{A}}{ }^{1}-t^{0}\right), \\
& E_{\mathrm{M}}=f\left(l^{*}=G_{\mathrm{M}} / G_{\mathrm{A}}, t_{\mathrm{P}}, t^{0}\right) ; E_{\mathrm{A}}=f\left(l^{*}=G_{\mathrm{M}} / G_{\mathrm{A}}, t_{\mathrm{P}}, t^{0}\right) .
\end{aligned}
$$

The following values of the thermal efficiency of the process for the real values of the cooling limitation $t^{0}$ were obtained: $l^{*}=G_{\mathrm{M}} / G_{\mathrm{A}}=1.5, E_{\mathrm{M}}=0.45 ; l^{*}=G_{\mathrm{M}} /$ $G_{\mathrm{A}}=1.0, E_{\mathrm{M}}=0.65 ; l^{*}=G_{\mathrm{M}} / G_{\mathrm{A}}=0.5, E_{\mathrm{M}}=0.89$. The increasing in the portion of the auxiliary flow consistently increases the cooling level of the main flow; at the same time the specific energy consumption for the unit of "product" is increased. A comparison between operation of IEC of air and IEC-Rg was made. The analysis was carried out for the following condition: $l^{*}=G_{\mathrm{M}} / G_{\mathrm{A}}=1.0$ or both schemes of IEC. The decreasing in temperature of the main air flow from $t_{\mathrm{M}}=26.5^{\circ} \mathrm{C}$ for $\operatorname{IEC}\left(t_{\mathrm{A}}=\right.$ $25.5^{0} \mathrm{C} ; \varphi_{\mathrm{A}}=95 \%$ ) to $t_{\mathrm{M}}=21.0^{\circ} \mathrm{C}$ for IEC-R (parameters of auxiliary air flow $t_{\mathrm{A}}=$ $27.0^{\circ} \mathrm{C}, \varphi_{\mathrm{A}}=100 \%$ ). Attention should be paid to the parameters of the auxiliary air flow at the exit of the IEC-Rg. Unlike the processes in IECg, the changing in the condition of auxiliary air flow in IEC-Rg takes place along the line of $\varphi_{\mathrm{A}}=100 \%$; this can result in decreasing of the efficiency of cooling. This circumstance is very important for the development of the evaporative cooling technique, but usually it is not considered in publications of recent years (Maisotsenko and Gillan, 2003; Pandelidis et al., 2015; USA Patent 2009/0007583; USA Patent 2004/0061245; USA Patent $6,494,107)$; this can result in distortion of the obtained results. The correct selection of the correlation of $l^{*}=G_{\mathrm{M}} / G_{\mathrm{A}}$ influences the nature of the process in IEC-Ra. The ratio of auxiliary air flow and flow of recirculating water also plays an important role. The comparative analysis of the operation of IEC and Chg (scheme is according to Fig. 1B) is presented in Fig. 4A. The analysis was carried out for the condition of $l^{*}=$ 

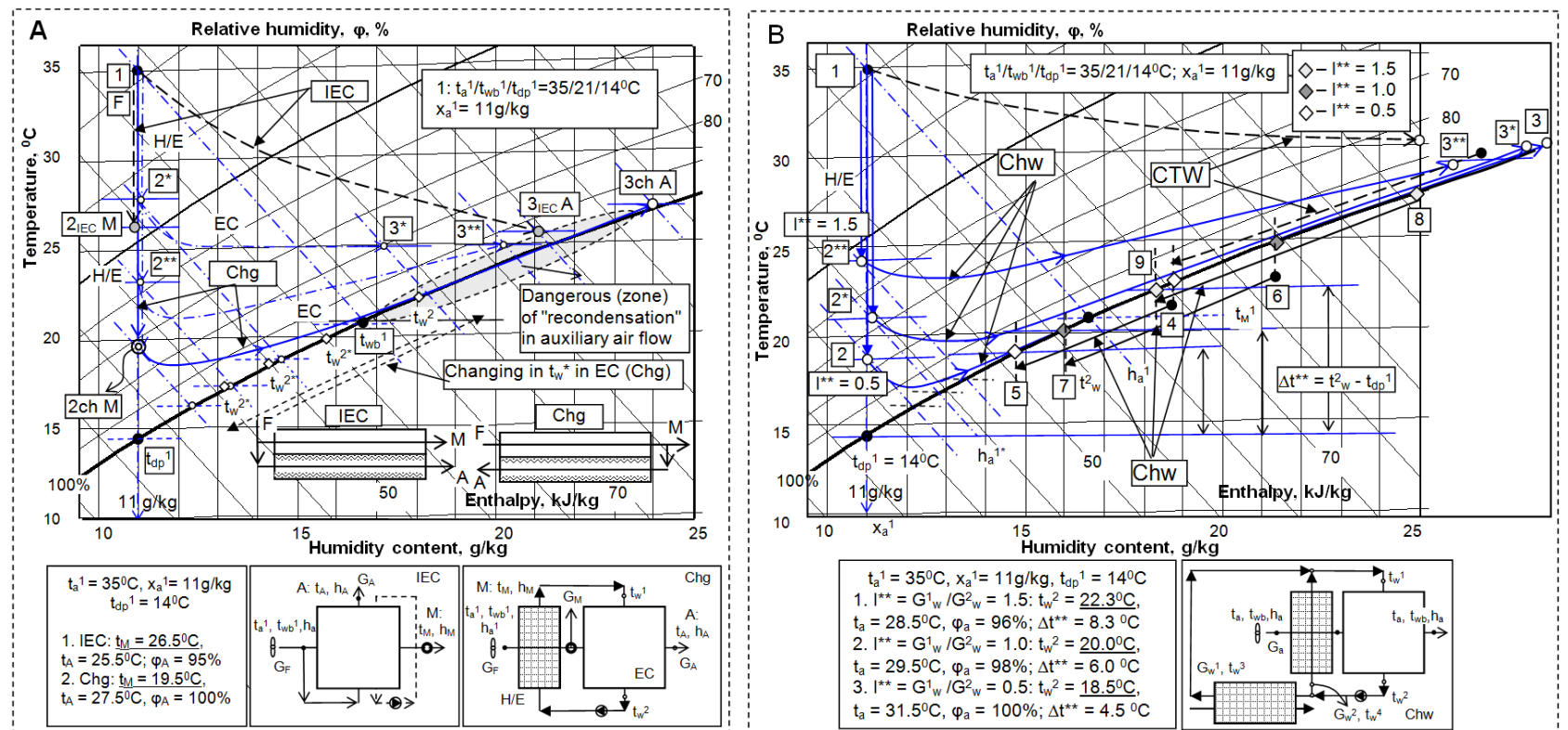

Fig. 4. A - operation of indirect evaporative air cooler (IECg (dotted line) and low temperature air cooler Chg (dash-dotted line))

$\mathrm{B}$ - operation of water chiller $\mathrm{Chw}$ depending on water flow rate ratios in main cooling loops

$G_{M} / G_{A}=1.0$ for both solutions. The conditional step analysis for Chg is presented: $1-2-3 \ldots$, dash-and-dot line $\left(1-3^{*}, 1-3^{* *}, 1-3 \mathrm{ch} \mathrm{A}\right.$, processes in evaporative cooler for auxiliary air flow); corresponding processes in heat exchanger (processes of cooling of main air flow "M" at constant humidity content) are presented by lines $1-2^{*}, 1-$ $2^{* *}, 1-2 \mathrm{ch} \mathrm{M}$. The changing in water temperature in the recirculating loop $\left(t_{\mathrm{w}}{ }^{2}\right)$ are shown on the equilibrium curve; for each step they match the corresponding value of wet bulb temperature of auxiliary air flow entering the evaporative cooler which was previously cooled in a heat exchanger. The resulting process of main air flow cooling is shown by solid line 1-2ch $\mathrm{M}$.

The following data was obtained (for initial conditions: $t_{a}{ }^{1}=35^{0} \mathrm{C}, x_{a}{ }^{1}=11 \mathrm{~g} / \mathrm{kg}$, $\left.\mathrm{t}_{\mathrm{dp}}{ }^{1}=14^{0} \mathrm{C}\right)$ :

$$
\begin{array}{r}
\text { IEC: } \underline{t}_{\underline{M}}=26.5^{0} \mathrm{C}, t_{\mathrm{A}}=25.5^{0} \mathrm{C} ; \varphi_{\mathrm{A}}=95 \% ; \\
\text { Chg: } \underline{t_{\mathrm{M}}}=19.5^{0} \mathrm{C}, t_{\mathrm{A}}=27.5^{0} \mathrm{C}, \varphi_{\mathrm{A}}=100 \% .
\end{array}
$$

Comparative capabilities of evaporative water chillers, CTWs, and Chw were studied (fig. 4B). The background for comparative analysis was the experimental data. Packing multichannel polymeric structures were used as heat and mass transfer apparatus: CTWs and chillers. The flow ratios in the main cooling loops in waterwater and water-air heat exchangers was $l^{* *}=G_{\mathrm{w}}^{1} / G^{2}{ }_{\mathrm{w}}$ at $l=G_{\mathrm{a}} / G_{\mathrm{w} \Sigma}=1.0$ for all analyzed variants of operation of Chw (where $G_{\mathrm{w} \Sigma}=G^{1}{ }_{\mathrm{w}}+G^{2}{ }_{\mathrm{w}}$ ). Processes in a cooling tower: 1-3 - for air, 5-6 - for cooling water. Processes in a Chw: 1-2-4 - for air, 78 - for cooling water. It can be seen that the degree of approximation to the cooling limitation (dew point temperature $t_{\mathrm{dp}}{ }^{1}$ ) is 9.5 и $6.0^{\circ} \mathrm{C}$ for compared cases, respectively. The analysis was carried out for Chw for different ratios of water in main cooling loops at $l^{* *}=G_{\mathrm{w}}^{1} / G_{\mathrm{w}}^{2}$. For initial conditions of $t_{\mathrm{a}}{ }^{1}=35^{\circ} \mathrm{C}, x_{\mathrm{a}}{ }^{1}=11 \mathrm{~g} \cdot \mathrm{kg}^{-1}, t_{\mathrm{dp}}{ }^{1}=$ $14^{\circ} \mathrm{C}$, the following data was obtained:

$$
\text { 1. } l^{* *}=G_{\mathrm{w}}^{1} / G_{\mathrm{w}}^{2}=1.5: t_{\mathrm{w}}{ }^{2}=22.3^{0} \mathrm{C} ; \Delta t^{* *}=8.3^{0} \mathrm{C} \text {; }
$$




$$
\begin{aligned}
& \text { 2. } l^{* *}=G^{1}{ }_{\mathrm{w}} / G^{2}{ }_{\mathrm{w}}=1.0: t_{\mathrm{w}}{ }^{2}=20.0^{0} \mathrm{C}, \Delta t^{* *}=6.0^{0} \mathrm{C} ; \\
& \text { 3. } l^{* *}=G^{1}{ }_{\mathrm{w}} / G^{2}{ }_{\mathrm{w}}=0.5: t_{\mathrm{w}}{ }^{2}=18.5^{0} \mathrm{C}, \Delta t^{* *}=4.5^{0} \mathrm{C} .
\end{aligned}
$$

It can be seen clearly that the increase in cold water portion entering the heat exchanger of preliminary cooling of air $\left(G_{\mathrm{w}}^{1}\right)$ leads to decreasing in chilled water temperature $t_{\mathrm{w}}^{2}$ : the value of $\Delta t^{* *}=\left(t_{\mathrm{w}}^{2}-t_{\mathrm{dp}}{ }^{1}\right)$ is $4.5^{0} \mathrm{C}$ for $l^{* *}=0.5$.

Two important issues should be noted here: the limit of cooling is related to the ratio of flow rates in evaporative cooler (CTW), and for the highest values of $l=$ $G_{\mathrm{a}} / G_{\mathrm{w}}$ it almost equals the natural limit (in this case this is the value of $t_{\mathrm{wb}}{ }^{1}$ ); for Chw with maximal value of $l^{* *}=G_{\mathrm{w}}^{1} / G^{2}{ }_{\mathrm{w}}(0.5)$ the line representing the changing conditions of the air flow in evaporative cooler almost coincides with the line of $\varphi=100 \%$.

Conclusions. Compared to indirect evaporative cooling in IECg, the cooling of air flow in a chiller air cooler Chg decreases the cooling limit of the main air flow lower than the wet bulb temperature of the ambient air; this increases the capabilities of the evaporative methods of cooling.

Compared to CTW, the cooling in water chiller Chw can provide a considerable decrease in temperature of cooling; the limitation of cooling in this case will be the dew point temperature of the ambient air; this expands substantially the boundaries of the practical application of such coolers; the further approximation to the limitation of cooling in Chw provides the variation of the ratio of the liquid flows in main cooling loops $l^{* *}=G_{\mathrm{w}}^{1} / G_{\mathrm{w}}^{2}$, and it can be decreased at the increase in $l=G_{\mathrm{a}} / G_{\mathrm{w}}^{\Sigma}$.

A transition to the "deep cooling" of water in Chw compared to CTW, will result in the increase in specific energy consumption; from this point of view, the study of optimal operation conditions of such water cooler is the most interesting, particularly, the study of the influence of contacting flow rate ratios of air and water $l=G_{\mathrm{a}} / G_{\mathrm{w}}$ on the efficiency of the process, as well as the influence of the value of $l^{* *}=G^{1}{ }_{\mathrm{w}} / G_{\mathrm{w}}^{2}$, flow rates of water in the main cooling loops of the chiller Chw.

Acknowledgements. The paper was financially supported in part by the Natural Science Foundation of China (Projects No. 51776187), Zhejiang Province Natural Science Foundation of China (Project No. LY16E060004), and by Ningbo Science and Technology Bureau from the International Cooperation Project No. 2017D10006.

\section{References:}

1. Chen G. M., Shestopalov K., Doroshenko A., Koltun P. Polymeric materials for solar energy utilization: a comparative experimental study and environmental aspects // Polymer-Plastics Technology and Engineering. - 2015. - Vol. 54. - P. 796-805.

2. Chen G. M., Doroshenko A., Shestopalov K. Solar absorption systems with heat and mass transfer apparatus with fluidized bed packing // Analysis and perspectives. Proceedings of the 6th International Conference on Cryogenics and Refrigeration, Shanghai, China. - 2018. - P. 413.

3. Doroshenko A. V., Glauberman M. A. Alternative energy. Refrigerating and Heating Systems, Odessa I.I. Mechnicow National University Press, 2012. - 430p.

4. Foster R. E., Dijkastra E. Evaporative air-conditioning fundamentals: environmental and economic benefits worldwide. // Proceedings of the IIR Conference on Applications for Natural Refrigerants, Aarhus, Denmark, IIF/IIR, 1996. - P. 101-109. 
5. Gomes E. V., Martinez F. J., Diez F. V., Leyva M. J., Martin R. H. Description and experimental results of a semi-indirect ceramic evaporative cooler // Int. J. Refrigeration. - 2005. - Vol. 28. - P. 654-662.

6. Koltun P., Ramakrishnan S., Doroshenko A., Kontsov M. Life Cycle Assessment of a Conventional and Alternantive Air-Conditioning Systems // Proceedings of the $21^{\mathrm{h}}$ International Congress of Refrigeration IIR/IIF, Washington, D.C, 2003. - P. 45-57.

7. John L., McNab, Paul, McGregor Dual indirect cycle air-conditioner uses heat concentrated desiccant and energy recovery in a polymer plate heat exchanger // Proceedings of the 21 International Congress of Refrigeration, IIR/IIF, Washington. 2003.

8. Maisotsenko, V., Lelland, Gillan, M. The Maisotsenko Cycle for Air Desiccant Cooling. Proceedings of the 21st Int. Congress of Refrigeration, Washington, D.C. 2003.

9. Martínez F. J., Gómez E. V., García C. M., Requena J. F., Gracia L. M., Navarro S. $H$, Guimaraes A. C., Gil J. M. Life cycle assessment of a semi-indirect ceramic evaporative cooler vs a heat pump in two climate areas of Spain. // Applied Energy. 2011. - Vol. 88. - P. 914-921.

10.Pandelidis D., Anisimov S., William M. Worec Performance study of the Maisotsenko Cycle heat exchangers in different air-conditioning applications // Int. J. of Heat and Mass Transfer. - 2015. - Vol. 81. - P. 207-221.

11.Patent USA: Indirect Evaporative Cooling Device (Pub. No.: US 2009/0007583 A1, Pub. Date: Jan. 8, 2009).

12. Patent USA: Maisotsenko et al. Indirect Evaporative Cooling Mechanism (Pub. No.: US 2004/0061245 A1, Pub. Date: Apr. 1, 2004).

13. Patent USA: Maisotsenko et al. Method and Apparatus of Indirect Evaporative Cooling. (Pub. No.: US 6,494,107 B2, Date: Dec. 24, 2002).

14. Stoitchkov N. J., Dimirov G. J. Effectiveness of crossflow plate heat exchanger for indirect evaporative cooling // Int. J. Refrigeration. - 1998. - Vol. 21(6). - P. 463471.

15.Zhao X., Liu S., Riffat S.B. Comparative study of heat and mass exchanging materials for indirect evaporative cooling systems. // Proceedings of the 43 th Int. Conf. Building and Environment, 2008. - P. 1902-1911.

\title{
Дорошенко А. В., Глауберман М. А., Шестопалов К.О., Бодня А. С., Халак В. Ф. Испарительные охладители газов и жидкостей с пониженным уровнем охлаждения
}

\begin{abstract}
АННОТАЦИЯ
Данное исследование посвящено разработке принципиальных решений систем охлаждения воздуха и кондиционирования воздуха, разработке оборудования для тепломассопереноса таких систем, экспериментальному исследованию и анализу принщипиальных возможностей таких систем на основе проведенных теоретических и экспериментальных исследований. Проведено теоретическое моделирование сопряженного прочесса тепломассопереноса в косвенных испарительных охладителях воды и воздуха. Показано, что температура точки росы воздушного потока, поступающего в испарительный охладитель, может служить ограничением охлаждения. Изучены трудности, связанные с получением ограничения охлаждения для низкотемпературного ох-
\end{abstract}


лаждения, связанного с возможной конденсацией водяных паров в воздушных потоках, когда воздушный поток, контактирующий с водой, до выхода из устройства тепломассопереноса полностью насыщиается.

Ключевые слова: испарительные охладители, естественное охлаждение, кондиционирование, энергосбережение.

\title{
Дорошенко О. В., Глауберман М. А., Шестопалов К. О., Бодня О. С., Халак В. Ф. Випарні охолоджувачі газів і рідин зі зниженим рівнем охолодження
}

\begin{abstract}
АНОТАЦИЯ
Інтерес до можливостей випарного охолодження середовищ в останні роки неухильно зростає, щчо обумовлено їх малим енергоспоживанням і екологічною чистотою. Широке практичне застосування знаходять випарні охолоджувачі прямого типу (повітроохолоджувачі $i$ водоохолоджувачі-градирні), $i$ непрямого типів (повітро- $i$ водоохолоджувачі). Можливості таких охолоджувачів по досягається температурному рівню охолодження обмежені температурою зовнішнього повітря по мокрому термометру є природним межею охолодження, їх ефективність істотно залежить від місцевих кліматичних умов. Значний інтерес в останні роки викликають випарні охолоджувачі зі зниженим межею випарного охолодження середовищ. Зниження температурного рівня охолодження забезпечує $i$ загальне зменшення кількості води, використовуваної в випарних охолоджувачах, що для сучасних енергетичних систем означає реальне зменшення кількості води, необхідну для компенсачї втрат на випаровування.

Розроблені принципові рімення випарних водо- $і$ повітряохолоджувачів непрямого типу (повітряних і водяних чілерів) з межею охолоджування, пониженою по відношенню до температури мокрого термометра повітряного потоку, щуо поступає в охолоджувач. Для низькотемпературних випарних охолоджувачів нового покоління иією межею є температура точки роси повітряного потоку, що поступає. Насадкова частина тепло-масообмінних апаратів плівкового типу виконана на основі багатоканальних композицій з полімерних матеріалів. Перехід на схемні рішення низькотемпературних випарних водо- $і$ повітряохолоджувачів забезпечує, порівняно до традиційного оформлення охолоджувача непрямого типу, істотне зниження температури охолоджуваного потоку, але вимагає розгляду небезпеки виникнення "реконденсації» в допоміжному повітряному потоці, щу безпосередньо контактує з водою, рециркулюючою крізь «мокру» частку апарату. Авторами запропонована математична модель прочесів спільного тепло-масообміну у випарних охолоджувачах газів і рідин непрямого тиny, щзо дозволяє врахувати небезпеку «реконденсації» в допоміжному повітряному потоиі, щуо принципово важливе при переході до низькотемпературного випарного охолоджування повітря або води. На підставі отриманих авторами експериментальних даних по ефективності прочесів тепло-масообміну виконано порівняльний аналіз можливостей розроблених охолоджувачів-чілерів. Показана небезпека реконденсаиії в допоміжному повітряному потоці із зростанням глибини охолоджування (зміна стану допоміжного повітряного потоку в низькотемпературному випарному охолоджувачі протікає уздовж лінії $\varphi_{6}=100 \%$, щุо може приводити до реконденсації $i$ зниженню ефективності охолоджування) $i$ запропоновані шляхи вирішення цієї проблеми. Це визначається, зокрема, правильним вибором співвідношення контактуючих повітряних потоків $l=G_{o} / G_{\partial}$ (основного $i$ допоміжного) для випарного воздухоохладителя $i l=G_{2}$ $/ G_{p}$ (газу і рідини) для випарного водоохолоджувача.
\end{abstract}

Ключові слова: випарні охолоджувачі, природне охолодження, кондиціонування повітря, енергозбереження. 